\title{
Acetylacetonato cobalt(III) and iron(III) complexes of picolylamine- and aminopropylamine-bis(phenolate) ligands: Synthesis, characterization and crystal structures.
}

Yasmine K. Redjel,,${ }^{a, b}$ Lucas Thevenin, ${ }^{a}$ Jean-Claude Daran, ${ }^{a}$ Meriem Benslimane, ${ }^{b}$ Rinaldo Poli ${ }^{a, c}$ and Christophe Fliedel ${ }^{a, *}$

$a$ Laboratoire de Chimie de Coordination (LCC-CNRS), Université de Toulouse, CNRS, INPT, UPS, 205 route de Narbonne, 31077 Toulouse Cedex 4, France

$b$ Unité de Recherche de Chimie de l'Environnement et Moléculaire Structurale, Faculté des Sciences Exactes, Département de Chimie, Université de Constantine 1, 25000 Constantine, Algeria

$c$ Institut Universitaire de France, 1 rue Descartes, 75231 Paris Cedex 05, France

* Corresponding author. E-mail address: christophe.fliedel@1cc-toulouse.fr

Dedicated to Professor William D. Jones on the occasion of his $65^{\text {th }}$ birthday.

\section{Keywords.}

Amino-phenolate ligands - Cobalt - Iron - Acetylacetonato (acac) complexes - X-ray crystallography 


\section{Abstract.}

The reaction between $\left[\mathrm{M}(\mathrm{acac})_{3}\right](\mathrm{M}=\mathrm{Fe}, \mathrm{Co}, \mathrm{acac}=$ acetylacetonate $)$ and the diamino-bis(phenol $)$ proligands (2-OH-3,5- $\left.{ }^{t} \mathrm{Bu}_{2}-\mathrm{C}_{6} \mathrm{H}_{2} \mathrm{CH}_{2}\right)_{2} \mathrm{NCH}_{2}\left(2-\mathrm{NC}_{5} \mathrm{H}_{4}\right) \quad\left(\mathrm{H}_{2} \mathbf{1}\right) \quad$ and $\quad$ (2-OH-5- ${ }^{t} \mathrm{Bu}-$ $\left.\mathrm{C}_{6} \mathrm{H}_{3} \mathrm{CH}_{2}\right)_{2} \mathrm{NCH}_{2} \mathrm{CH}_{2} \mathrm{CH}_{2} \mathrm{~N}\left(\mathrm{CH}_{3}\right)_{2}\left(\mathrm{H}_{2} 2\right)$ afforded the $\left[\kappa^{4}-\left(N_{2}, O_{2}\right) \mathrm{M}(\mathrm{acac})\right]$ complexes [ $\left.\mathrm{Fe}(\mathbf{1})(\mathrm{acac})\right](\mathbf{3})$, $[\mathrm{Fe}(\mathbf{2})(\mathrm{acac})](\mathbf{4}),[\mathrm{Co}(\mathbf{1})(\mathrm{acac})](\mathbf{5})$ and $[\mathrm{Co}(\mathbf{2})(\mathrm{acac})](\mathbf{6})$ in moderate yields after crystallization. The proposed formulas were supported by various analytical data (ESI-MS, FT-IR, EA, NMR), and the molecular structure of all complexes was confirmed by X-ray diffraction studies. In each octahedral complex, the diamino-bis(phenolate) ligand ( 1 or $\mathbf{2}$ ) acts as a tetradentate ligand and the coordination sphere is completed by one chelating $\kappa^{2}-O_{2}$ acac ligand. Although the previously reported ligand $\mathbf{1}$ and the new ligand 2 are very similar, their coordination to the $\mathrm{Fe}^{\mathrm{III}}(\mathrm{acac})$ or $\mathrm{Co}^{\mathrm{III}}(\mathrm{acac})$ moieties varies by the arrangement of the donor atoms. While the $O_{\text {phenolate }}$ donor atoms of ligand $\mathbf{1}$ were found cis to each other in the $\mathrm{Fe}^{\mathrm{III}}$ complex $\mathbf{3}$, they are trans in the $\mathrm{Co}^{\mathrm{III}}$ complex $\mathbf{5}$, and vice versa for ligand $\mathbf{2}$. Since each ligand, 1 and $\mathbf{2}$, exhibits both configuration, this structural curiosity cannot be easily explained on the basis of steric factors, i.e. ortho-substituents or $N, N^{\prime}$-linker length. 


\section{Introduction.}

The development of various tetradentate amino-bis(phenolate) $\left(\mathrm{O}_{2} \mathrm{ND}\right.$, with $\mathrm{D}=$ extra donor such as $\mathrm{N}$, $\mathrm{O}, \mathrm{S} . .$.$) ligands and the study of their coordination chemistry gain increasing attention since the seminal$ work of Spence and coworkers in 1989 [1]. While several articles deal solely with the preparation and (structural) characterization of new metal complexes, another large number of reports takes advantage of the specific architecture of this type of ligands and of their facile stereo-electronic tuning by modification of the fourth donor and substitution of the phenol rings to develop new metal catalysts. As well summarized by Wichmann et al. in 2012, early catalytic applications mostly involved early transition and rare earth metal centers, while late transition metals were preferably used for the synthesis of model compounds for biological processes [2]. The use of diamino-bis(phenolate) late transition metal complexes in catalysis is more recent and limited to reactions such as cross-couplings [3,4] and the conversion of $\mathrm{CO}_{2}$ and epoxides to cyclic carbonates and/or polycarbonates [5, 6].

Our research group has been interested for a few years in organometallic-mediated radical polymerization (OMRP), a technique in which the control of the polymerization lies on the reversible equilibrium between an active radical species and a metal complex in its low oxidation state and a dormant organometallic species (Scheme 1) [7-12]. Aspects that attract our attention are the development of new OMRP moderators [13-18], the interplay of RT and DT mechanisms during the OMRP process [15, 18, 19], the influence of the metal coordination sphere [16, 17, 20] and of the reaction medium composition $[17,18,21]$ and the mechanism of metal-catalyzed termination reactions [22, 23]. As notable results, the occurrence of catalytic chain transfer (CCT) in vinyl acetate (VAc) polymerization [13] and the radical polymerization of vinylidene fluoride (VDF) with an unprecedented level of control [24], both with cobalt complexes as moderators, were very recently reported for the first time. The replacement of cobalt by a less toxic metal such as iron has triggered many investigations, including by our group [14], but improvements are still needed to compete with the best cobalt complexes [25]. In this context, Shaver and coworkers showed that iron(III) halide complexes of amino-bis(phenolate) ligands are effective moderators for the controlled polymerization of styrene derivatives and methyl methacrylate (MMA) [26, 27]. However, the good performances of these systems are mostly due to an atom-transfer radical polymerization (ATRP) mechanism, because analogous $\mathrm{Fe}^{\mathrm{II}}$ system, in combination with a non-halogenated radical initiator (i.e. OMRP conditions), were found less effective [28]. Although these results have a certain importance, they concern the polymerization of "more-activated monomers" (MAMs). Exploring the controlled radical polymerization of "less-activated monomers" (LAMs) with iron complexes remains a challenge. The development of single-component OMRP initiators, i.e. metal complexes incorporating a metal-R bond (e.g. with $\mathrm{R}=$ functionalized alkyl group) that can be homolytically cleaved to generate radicals is of great 
interest to start radical polymerizations without the need of "classical" sensitive azo-initiators, and for postpolymerization functionalization, depending on the nature of the $\mathrm{R}$ group [29].

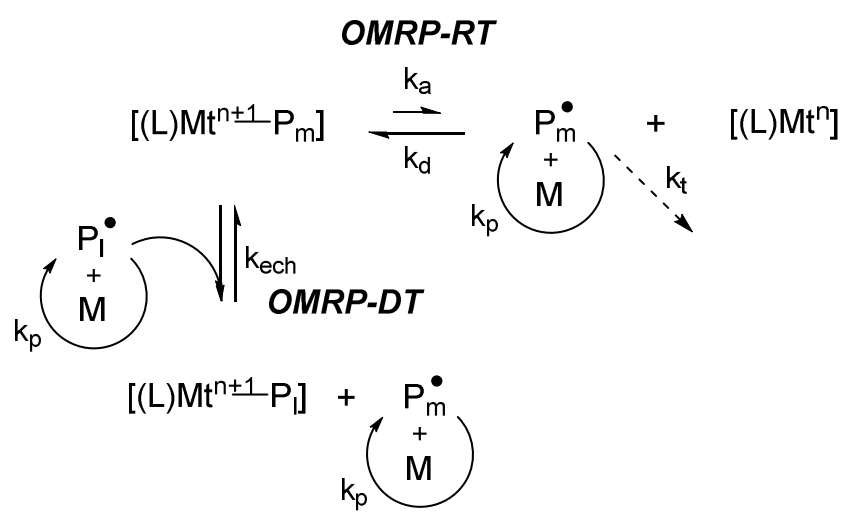

Scheme 1. (a) Reversible termination (RT) and (b) degenerative transfer (DT) equilibria involved in OMRP. $\mathrm{M}=$ monomer, $(\mathrm{L}) \mathrm{Mt}=$ transition metal complex, $\mathrm{P}_{\mathrm{m}, \mathrm{l}}=$ propagating polymer chain .

In this contribution, we report the development of metal complexes of the type $\left[\left(O_{2}, N_{2}\right) \mathrm{M}^{\mathrm{III}}(\mathrm{acac})\right](\mathrm{M}$ $=\mathrm{Fe}, \mathrm{Co})$ and their evaluation as single-component initiators/moderators for radical polymerization, via formation of an acac radical. In case of success, these complexes would represent easily accessible, stable and easy to handle radical initiators/moderators and stand as viable alternative to bi-component systems based on temperature sensitive radical initiators and easily oxidized $\mathrm{M}^{\mathrm{II}}$ moderators or other air-, temperature- and/or UV-sensitive single component initiators such as organometallic compounds with homolytically fragile M-C bonds. The use of metal acetylacetonate complexes as radical sources has been little explored, but uncontrolled radical polymerizations were observed in a few instances [30, 31].

\section{Experimental Part}

General Considerations. Only the polymerization tests were conducted under inert atmosphere (Ar) and in flame-dried glassware (see below). All other operations were carried out in air and using non-dried glassware and solvents.

Materials. The metal precursors $\left[\mathrm{Fe}(\mathrm{acac})_{3}\right] 99 \%$ and $\left[\mathrm{Co}(\mathrm{acac})_{3}\right] 98+\%$ were purchased from Strem Chemicals. Compounds 3-(dimethylamino)-1-propylamine (Alfa Aesar, 99\%), 4-(tert-butyl)phenol (Alfa Aesar, 99\%), 2-aminomethyl-pyridine (Apollo Scientific, 98\%), 2,4-di-(tert-butyl)phenol (Fluka, 97\%), formaldehyde solution (Alfa Aesar, 37\% in water), triethylamine (Acros Organics, $99 \%$ ) and $\mathrm{CDCl}_{3}$ $(99.8 \% \mathrm{D}$, Euriso-top) were used as received, without prior purification. Methyl methacrylate (Aldrich, 99\%), Vinyl acetate (Acros Organics, 99\%) and tert-butyl acrylate (Aldrich, 98\%) were distilled under 
argon, degassed by several freeze/pump/thaw cycles and stored under argon. Laboratory Reagent grade ( $\geq 99.5 \%$ ) chloroform, toluene, methanol and ethanol were purchased from VWR Chemicals and used as received, without prior purification.

Instrumentation. The NMR spectra were recorded on a Bruker Avance III 300 or $400 \mathrm{MHz}$ spectrometer at ambient temperature. ${ }^{1} \mathrm{H}$ and ${ }^{13} \mathrm{C}$ chemical shifts $(\delta)$ are reported in ppm vs. $\mathrm{SiMe}_{4}$ and were determined by reference to the residual ${ }^{1} \mathrm{H}$ and ${ }^{13} \mathrm{C}$ solvent peaks. The coupling constants are reported in Hertz. The IR spectra were recorded in the $4000-100 \mathrm{~cm}^{-1}$ region on a PerkinElmer Frontier FT-IR spectrometer (ATR mode, Diamond crystal). The electrospray mass spectra (ESI-MS) were recorded on a Q-Tof Premier (Waters) instrument using nitrogen as drying agent and nebulizing gas and $\mathrm{MeCN}$ as solvent. The elemental analyses for all compounds were performed by the analytical service of the LCC-Toulouse using a PerkinElmer 2400 CHNS/O Series II System (100V).

X-ray structural analyses. A single crystal of each compound was mounted under inert perfluoropolyether at the tip of a glass fiber and cooled in the cryostream of either a Rigaku OxfordDiffraction XCALIBUR Gemini EOS diffractometer for $\mathbf{4} \cdot \mathrm{MeOH}$, or a Nonius Bruker APEXII diffractometer for $\mathrm{H}_{3} 2^{+} \mathrm{Cl}^{-}, 3,5,6$ and 7 .

The structures were solved by using the integrated space-group and crystal structure determination SHELXT software [32] and refined by least-squares procedures on $F^{2}$ using SHELXL-2014 [33]. All H atoms attached to carbon or oxygen atoms were introduced in the calculations at idealised positions and treated according to the riding model. In three of the six compounds, there is more than one molecule within the asymmetric unit: three molecules for compound 3 and two for $4 \cdot \mathrm{MeOH}$ and $\mathbf{5}$. In five of the six compounds, a few $t \mathrm{Bu}$ atoms appear with elongated ellipsoids and have been treated as disordered using the tools available in SHELXL-2014. In compound 6, difference Fourier syntheses revealed some residual electron densities which could be attributed to methanol and water molecules. However, these molecules appear to be highly disordered and it was difficult to model their positions and distribution reliably. Therefore, the SQUEEZE function of PLATON [34] was used to eliminate the contribution of the electron density in the solvent region from the intensity data and the solvent-free model was employed from the final refinement. The absolute structure for compound $\mathbf{4}$, which crystallized in the $\mathrm{P} 2{ }_{1}{ }_{2}{ }_{1}{ }_{1}$ space group, has been determined by refining the Flack's parameter [35]. Crystal data and refinement parameters are shown in Table 2 and Table 3. 


\section{Synthesis of ligand $\mathrm{H}_{2} 2$.}

3-(dimethylamino)-1-propylamine $(7.74 \mathrm{~mL}, 0.06 \mathrm{~mol})$ was added to a mixture of 4-(tert-butyl)phenol (18.48 g, $0.12 \mathrm{~mol})$ and formaldehyde $\left(37 \%\right.$ in $\left.\mathrm{H}_{2} \mathrm{O}, 10 \mathrm{~mL}, 0.12 \mathrm{~mol}\right)$ in water/ethanol $(70+30 \mathrm{~mL}$, respectively) at room temperature. The resulting reaction mixture was stirred for $18 \mathrm{~h}$ at $70^{\circ} \mathrm{C}$. After cooling the homogenous solution to $0^{\circ} \mathrm{C}$, a white solid corresponding to the desired proligand $\mathrm{H}_{2} 2$ precipitated. The white precipitate was filtered off, washed with cold ethanol $(3 \times 20 \mathrm{~mL})$ and dried under vacuum $(15.50 \mathrm{~g}$, 58\% yield). Anal. calcd for $\mathrm{C}_{27} \mathrm{H}_{42} \mathrm{~N}_{2} \mathrm{O}_{2}$ (426.65): C 76.01; $\mathrm{H} 9.92 ; \mathrm{N} 6.57$; found: $\mathrm{C} 75.95, \mathrm{H} \mathrm{10.02}, \mathrm{N}$ 6.61. ${ }^{1} \mathrm{H}$ NMR (400 MHz, $\mathrm{CDCl}_{3}$ ): $\delta 1.29$ (s, $\left.18 \mathrm{H}, \mathrm{C}\left(\mathrm{CH}_{3}\right)_{3}\right), 1.84\left(\mathrm{q},{ }^{3} \mathrm{~J}=6.0 \mathrm{~Hz}, 2 \mathrm{H}, \mathrm{CH}_{2} \mathrm{CH}_{2} \mathrm{CH}_{2}\right.$ ), 2.34 (s, $\left.6 \mathrm{H}, \mathrm{N}\left(\mathrm{CH}_{3}\right)_{2}\right), 2.51\left(\mathrm{t},{ }^{3} \mathrm{~J}=6.0 \mathrm{~Hz}, 2 \mathrm{H}, \mathrm{CH}_{2} \mathrm{~N}\left(\mathrm{CH}_{2}\right)_{2}\right), 2.62\left(\mathrm{q},{ }^{3} \mathrm{~J}=6.0 \mathrm{~Hz}, 2 \mathrm{H}, \mathrm{CH}_{2} \mathrm{NMe}_{2}\right), 3.65(\mathrm{~s}, 4 \mathrm{H}$, $\left.\mathrm{N}\left(\mathrm{CH}_{2}\right)_{2}\right), 6.80\left(\mathrm{~d},{ }^{3} J=8.5 \mathrm{~Hz}, 2 \mathrm{H}, \mathrm{H}_{\text {arom }}, o-\mathrm{OH}\right), 7.03\left(\mathrm{~d},{ }^{4} J=2.5 \mathrm{~Hz}, 2 \mathrm{H}, \mathrm{H}_{\text {arom }}, o-\mathrm{CH}_{2}\right), 7.19\left(\mathrm{dd},{ }^{3} J=8.5\right.$

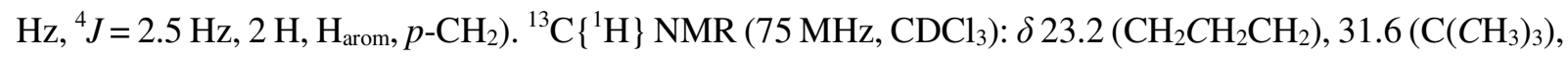

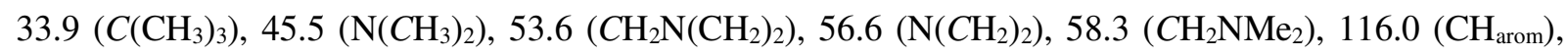
$121.5\left(\mathrm{C}_{\text {quat }}\right), 125.8\left(\mathrm{CH}_{\text {arom }}\right), 127.2\left(\mathrm{CH}_{\text {arom }}\right), 141.8\left(\mathrm{C}_{\text {quat }}\right), 154.4\left(\mathrm{C}_{\text {quat }}\right)$. FTIR: $v_{\max }($ solid $) / \mathrm{cm}^{-1}: 2949 \mathrm{br}$, 2872br, 1598br, 1504m, 1489w, 1471m, 1451m, 1440m, 1426w, 1398w, 1364m, 1352w, 1276vs, 1252s, 1225w, 1190w, 1178w, 1135w, 1090m, 1015m, 888m, 822vs, 812vs, 770m, 673m, 656s, 588m, 452m, 437m, 419m. MS (ESI): $m / z 449.3[\mathrm{M}+\mathrm{Na}]$.

\section{Synthesis of complex [Fe(1)(acac)] (3).}

Solid [Fe(acac) $)_{3}$ (64 mg, $\left.0.18 \mathrm{mmol}\right)$ was added to a solution of pro-ligand $\mathrm{H}_{2} \mathbf{1}(100 \mathrm{mg}, 0.18 \mathrm{mmol})$ and excess $\mathrm{NEt}_{3}(0.5 \mathrm{~mL})$ in $\mathrm{MeOH} / \mathrm{CHCl}_{3}(20+10 \mathrm{~mL})$, yielding an immediate color change from orange to dark red. The resulting mixture was stirred at room temperature for $24 \mathrm{~h}$. Evaporation to dryness afforded a microcrystalline dark red powder, which was recrystallized from $\mathrm{CHCl}_{3}$, affording pure complex $\mathbf{3}$ as black crystals ( $58 \mathrm{mg}, 46 \%$ yield). Suitable crystals for X-ray diffraction analysis were grown by slow evaporation of a saturated $\mathrm{CHCl}_{3}$ solution of $\mathbf{3}$ at room temperature over a week. Anal. calcd for $\mathrm{C}_{41} \mathrm{H}_{57} \mathrm{FeN}_{2} \mathrm{O}_{4}$ (697.76): C 70.58; H 8.23; N 4.01; found: C 70.49, H 8.33, N 4.08. FTIR: $v_{\max }(\mathrm{solid}) / \mathrm{cm}^{-1}$ : 2950w, 1588m, 1522s, 1496s, 1490s, 1456m, 1386m, 1374m, 1361s, 1301s, 1273vs, 1261s, 1184w, 1091w, 1016m, 962w, 928w, 887w, 834s, 828vs, 812sh, 789m, 770m, 733w, 672m, 655m, 545s, 522s, 432vs, $411 \mathrm{~s}$. MS (ESI): $m / z, 720.3[\mathrm{M}+\mathrm{Na}]$. 


\section{Synthesis of complex [Fe(2)(acac)] (4).}

The same procedure as for 3 was used with [Fe(acac) 3 ] (177 mg, $0.5 \mathrm{mmol}$ ), pro-ligand $\mathrm{H}_{2} \mathbf{2}$ (213 mg, 0.5 $\mathrm{mmol})$ and $\mathrm{NEt}_{3}(0.5 \mathrm{~mL})$ in $\mathrm{MeOH}(30 \mathrm{~mL})$. Instead of room temperature, the mixture was heated at reflux for $24 \mathrm{~h}$. Complex 4 was isolated as black crystals (151 mg, 52\% yield). Suitable crystals for X-ray diffraction analysis were grown by slow evaporation of a saturated $\mathrm{MeOH}$ solution of $\mathbf{4}$ at room temperature over five days. Anal. calcd for $\mathrm{C}_{32} \mathrm{H}_{47} \mathrm{FeN}_{2} \mathrm{O}_{4}$ (579.58): C 66.32; H 8.17; N 4.83; found: $\mathrm{C} 66.15, \mathrm{H}$ 8.18, N 4.77. FTIR: $v_{\max }\left(\right.$ solid) $/ \mathrm{cm}^{-1}: 2951 \mathrm{br}, 1587 \mathrm{~m}, 1521 \mathrm{~s}, 1490 \mathrm{~s}, 1456 \mathrm{~m}, 1373 \mathrm{~s}, 1361 \mathrm{~s}, 1307 \mathrm{~s}, 1273 \mathrm{~s}, 1261 \mathrm{~s}$, 1184w, 1130w, 1102w, 1073w, 1018m, 985w, 961w, 928w, 879w, 828vs, 813s, 789s, 733w, 695w, 667m, 653w, 610w, 600w, 544s, 522s, 433vs, 407m. MS (ESI): m/z 602.3 [M + Na].

\section{Synthesis of complex [Co(1)(acac)] (5).}

The same procedure as for 3 was used with $\left[\mathrm{Co}(\mathrm{acac})_{3}\right]$ ( $\left.65 \mathrm{mg}, 0.18 \mathrm{mmol}\right)$, pro-ligand $\mathrm{H}_{2} \mathbf{1}$ (100 $\mathrm{mg}, 0.18$ $\mathrm{mmol})$ and $\mathrm{NEt}_{3}(0.5 \mathrm{~mL})$ in $\mathrm{MeOH} / \mathrm{CHCl}_{3}(20+10 \mathrm{~mL})$. Complex 5 was isolated as black crystals (66 $\mathrm{mg}, 52 \%$ yield). Suitable crystals for X-ray diffraction analysis were grown by slow evaporation of a saturated $\mathrm{MeOH} / \mathrm{CHCl}_{3}$ solution of 5 at room temperature over two weeks. Anal. calcd for $\mathrm{C}_{41} \mathrm{H}_{57} \mathrm{CoN}_{2} \mathrm{O}_{4}$ (700.85): C 70.26; $\mathrm{H} 8.20$; N 4.00; found: $\mathrm{C} 70.44, \mathrm{H} 8.26, \mathrm{~N} 3.89 .{ }^{1} \mathrm{H}$ NMR (300 MHz, $\mathrm{CDCl}_{3}$ ): $\delta 1.15$ (s, $\left.18 \mathrm{H}, \mathrm{C}\left(\mathrm{CH}_{3}\right)_{3}\right), 1.23$ (s, $\left.18 \mathrm{H}, \mathrm{C}\left(\mathrm{CH}_{3}\right)_{3}\right), 2.04$ (s, 3H, $\mathrm{CH}_{3}$ acac), 2.40 (s, 3H, $\mathrm{CH}_{3}$ acac), 3.02 (br, $2 \mathrm{H}$, $\mathrm{NCH}_{2} \mathrm{Phenol}$ ), 4.16 (s, 2H, NCH $\mathrm{N}_{2} \mathrm{Py}$ ), 4.98 (br, 2H, NCH $\mathrm{Nhenol}_{2}, 5.58$ (s, $1 \mathrm{H}, \mathrm{CH}$ acac), 6.65 (d, $1 \mathrm{H},{ }^{3} \mathrm{~J}=$ $7.8 \mathrm{~Hz}, \mathrm{H}_{\text {arom }}, \mathrm{Py}$ ), 6.82 (s, 2H, $\mathrm{H}_{\text {arom, }}$ Phenol), 6.86 (s, 2H, $\mathrm{H}_{\text {arom, }}$ Phenol), 7.10 (dd, 1H, ${ }^{3} J=7.8 \mathrm{~Hz}, \mathrm{H}_{\text {arom, }}$ Py), 7.38 (dd, $\left.1 \mathrm{H},{ }^{3} J=7.5 \mathrm{~Hz}, \mathrm{H}_{\text {arom }}, \mathrm{Py}\right), 9.19$ (d, 1H, ${ }^{3} \mathrm{~J}=7.5 \mathrm{~Hz}, \mathrm{H}_{\text {arom }}$, Py). ${ }^{13} \mathrm{C}\left\{{ }^{1} \mathrm{H}\right\}$ NMR $(100 \mathrm{MHz}$, $\left.\mathrm{CDCl}_{3}\right): \delta 26.2\left(\mathrm{CH}_{3} \mathrm{acac}\right), 26.6\left(\mathrm{CH}_{3} \mathrm{acac}\right), 29.8\left(\mathrm{C}_{\left.\left(\mathrm{CH}_{3}\right)_{3}\right),} 31.9\left(\mathrm{C}_{\left.\left(\mathrm{CH}_{3}\right)_{3}\right),} 63.0\left(\mathrm{NCH}_{2} \mathrm{Py}\right), 64.2\right.\right.$ ( $\left.\mathrm{NCH}_{2} \mathrm{Phenol}\right), 97.8$ ( $\left.\mathrm{CH} \mathrm{acac}\right), 118.1$ ( $\left.\mathrm{CH}_{\text {arom }} \mathrm{Py}\right), 120.4\left(\mathrm{C}_{\text {quat }}\right), 121.1\left(\mathrm{CH}_{\text {arom }} \mathrm{Py}\right), 123.0\left(\mathrm{CH}_{\text {arom }}\right.$ Phenol$)$, 123.6 ( $\mathrm{CH}_{\text {arom }}$ Phenol), $134.4\left(\mathrm{C}_{\text {quat }}\right), 137.5\left(\mathrm{CH}_{\text {arom }}\right.$ Py $), 140.6\left(\mathrm{C}_{\text {quat }}\right), 150.2\left(\mathrm{CH}_{\text {arom }}\right.$ Py $), 162.6\left(\mathrm{C}_{\text {quat }}\right), 162.8$ ( $\mathrm{C}_{\text {quat }}$ ), 187.4 (CO acac), 187.9 (CO acac). FTIR: $v_{\max }\left(\right.$ solid)/cm ${ }^{-1}: 2949 \mathrm{br}, 1577 \mathrm{br}, 1464 \mathrm{~s}, 1457 \mathrm{~s}, 1435 \mathrm{~s}$, $1410 \mathrm{w}, 1404 \mathrm{~m}, 1315 \mathrm{~m}, 1297 \mathrm{~m}, 1289 \mathrm{~m}, 1278 \mathrm{sh}, 1264 \mathrm{~s}, 1245 \mathrm{~m}, 1227 \mathrm{~s}, 1155 \mathrm{w}, 1130 \mathrm{~m}, 1029 \mathrm{~m}, 1023 \mathrm{sh}$, 855m, 848s, 839vs, 766m, 751vs, 729s, 686m, 650m, 593m, 577vs, 556s, 547m, 473w, 443w, 407s. MS (ESI): $m / z 723.4[\mathrm{M}+\mathrm{Na}]$. 


\section{Synthesis of complex $[\mathrm{Co}(2)(\mathrm{acac})](6)$.}

The same procedure as for 4 was used with $\left[\mathrm{Co}(\mathrm{acac})_{3}\right](178 \mathrm{mg}, 0.5 \mathrm{mmol})$, pro-ligand $\mathrm{H}_{2} \mathbf{2}(213 \mathrm{mg}, 0.5$ $\mathrm{mmol})$ and $\mathrm{NEt}_{3}(0.5 \mathrm{~mL})$ in $\mathrm{MeOH}(30 \mathrm{~mL})$. Complex 6 was isolated as black crystals $(157 \mathrm{mg}, 54 \%$ yield). Suitable crystals for $\mathrm{X}$-ray diffraction analysis were grown by slow evaporation of a saturated $\mathrm{MeOH}$ solution of 6 at room temperature over a week. Anal. calcd for $\mathrm{C}_{32} \mathrm{H}_{47} \mathrm{CoN}_{2} \mathrm{O}_{4}$ (582.67): $\mathrm{C}$ 65.96; $\mathrm{H}$ 8.13; $\mathrm{N}$ 4.81; found: $\mathrm{C}$ 65.81, $\mathrm{H}$ 8.22, N 4.74. ${ }^{1} \mathrm{H}$ NMR (300 MHz, $\mathrm{CDCl}_{3}$ ): $\delta 1.29$ (s, $\left.18 \mathrm{H}, \mathrm{C}\left(\mathrm{CH}_{3}\right)_{3}\right), 1.65$ (s, $\left.3 \mathrm{H}, \mathrm{N}\left(\mathrm{CH}_{3}\right)\right), 1.83$ (s, 3H, N(CH3)), 2.07 (m, 2H, $\mathrm{CH}_{2} \mathrm{CH}_{2} \mathrm{CH}_{2}$ ), 2.21 (s, 3H, $\mathrm{CH}_{3} \mathrm{acac}$ ), 2.35 (s, 3H, $\mathrm{CH}_{3}$ acac), 2.49 (br, $\left.2 \mathrm{H}, \mathrm{CH}_{2} \mathrm{~N}\left(\mathrm{CH}_{2}\right)_{2}\right), 2.87$ (m, 2H, $\mathrm{CH}_{2} \mathrm{NMe}_{2}$ ), 3.42 (br, $2 \mathrm{H}, \mathrm{NCH} \mathrm{H}_{2} \mathrm{Phenol}$ ), 3.47 (br, $2 \mathrm{H}$, $\mathrm{NCH}_{2}$ Phenol), 5.54 (s, $1 \mathrm{H}, \mathrm{CH}$ acac), 6.73-7.25 (m, 6H, $\mathrm{H}_{\text {arom }}$, Phenol). ${ }^{13} \mathrm{C}\left\{{ }^{1} \mathrm{H}\right\}$ NMR (100 MHz, $\left.\mathrm{CDCl}_{3}\right)$ : $\delta 25.9\left(\mathrm{CH}_{3} \mathrm{acac}\right), 26.0\left(\mathrm{CH}_{3} \mathrm{acac}\right), 29.7\left(\mathrm{CH}_{2} \mathrm{CH}_{2} \mathrm{CH}_{2}\right), 30.1\left(\mathrm{~N}_{\left.\left(\mathrm{CH}_{3}\right)_{2}\right),} 31.6\left(C\left(\mathrm{CH}_{3}\right)_{3}\right), 44.5\left(\mathrm{NCH}_{2}\right)\right.$, $46.3\left(\mathrm{NCH}_{2}\right), 63.3\left(\mathrm{NCH}_{2} \mathrm{Phenol}\right), 97.4(\mathrm{CH}$ acac$), 121.5\left(\mathrm{C}_{\text {quat }}\right), 125.9\left(\mathrm{CH}_{\text {arom }}\right.$ Phenol), $127.2\left(\mathrm{CH}_{\text {arom }}\right.$ Phenol), 129.7 ( $\mathrm{CH}_{\text {arom }}$ Py), 141.6 ( $\left.\mathrm{C}_{\text {quat }}\right), 154.4$ ( $\left.\mathrm{C}_{\text {quat }}\right), 196.8$ (CO acac), 196.9 (CO acac). FTIR: $v_{\max }($ solid $) / \mathrm{cm}^{-1}: 2951 \mathrm{br}, 1605 \mathrm{br}, 1520 \mathrm{w}, 1490 \mathrm{vs}, 1391 \mathrm{~m}, 1361 \mathrm{~m}, 1283 \mathrm{~s}, 1260 \mathrm{vs}, 1133 \mathrm{mw}, 1106 \mathrm{w}, 1019 \mathrm{w}$, 953w, 881w, 829vs, 687m, 610w, 552m, 523m, 453m, 410w. MS (ESI): m/z 605.3 [M + Na].

\section{General procedure for the polymerization tests.}

All polymerization tests were carried out under a protective argon atmosphere, in flame-dried glassware and using distilled and degassed monomers and solvents.

The polymerization tests with methyl methacrylate (MMA) as monomer were conducted similarly to the procedure described by Kalpagam and coworkers [30], using both the Fe complex 4 and the Co complex 5 . As representative procedure, a Schlenk tube was charged with MMA (3.0 mL, $28.2 \mathrm{mmol})$, toluene (3.0 $\mathrm{mL}), 1.0 \mathrm{~mL}$ of a stock solution of complex $5\left(2 \mathrm{mg}, 3.4310^{-3} \mathrm{mmol}\right.$, in $10 \mathrm{~mL}$ of toluene) and $0.3 \mathrm{~mL}$ of mesitylene as internal reference. The reaction mixture was degassed by two freeze/pump/thaw cycles, followed by immersion in an oil bath at $70{ }^{\circ} \mathrm{C}$. Aliquots were withdrawn after 1 and $3 \mathrm{~h}$ and analyzed by ${ }^{1} \mathrm{H}$ NMR, and no conversion was observed.

A similar procedure was used with vinyl acetate (VAc) as monomer and complexes $4(\mathrm{Fe})$ or $5(\mathrm{Co})$. See for example the quantities used for 5: VAc $(2.6 \mathrm{~mL}, 28.3 \mathrm{mmol})$, toluene $(3.0 \mathrm{~mL}), 1.0 \mathrm{~mL}$ of a stock solution of complex 5 (2 mg, $3.4310^{-3} \mathrm{mmol}$, in $10 \mathrm{~mL}$ of toluene) and $0.26 \mathrm{~mL}$ of mesitylene. No polymerization was observed over a period of $18 \mathrm{~h}$ at $70{ }^{\circ} \mathrm{C}$. 
Polymerization test with tert-butyl acrylate (tBA) in bulk conditions. Complex 4 (30 mg, 0.05 mmol, 1 eq.) was introduced in a Schlenk tube and purged by three vacuum-argon cycles, followed by the addition of degassed tert-butyl acrylate $(5.6 \mathrm{~mL}, 38 \mathrm{mmol}, 760$ eq.). The reaction mixture was degassed by two freeze/pump/thaw cycles, followed by immersion in an oil bath at $60{ }^{\circ} \mathrm{C}$. An aliquot was withdrawn after 1 $\mathrm{h}$ and analyzed by ${ }^{1} \mathrm{H}$ NMR. Since no conversion was observed, the temperature was increased gradually to $90(1 \mathrm{~h}), 110(1 \mathrm{~h})$ and $130{ }^{\circ} \mathrm{C}(3 \mathrm{~h})$, without observation of any polymerization.

\section{Results and discussion.}

The picolyl-based diamino-bis(phenol) pro-ligand $\mathrm{H}_{2} \mathbf{1}$ was prepared following a previously reported procedure (Scheme 2) [36]. The new pro-ligand $N$-(3-dimethylaminopropyl)- $N, N$-bis-[2'-hydroxy-5'-tertbutyl-benzyl]-amine $\left(\mathrm{H}_{2} 2\right)$ was synthesized similarly, in reasonable yields $(58 \%)$, by a Mannich reaction between 3-(dimethylamino)-1-propylamine, paraformaldehyde and 4-tert-butylphenol (Scheme 2). Proligands $\mathrm{H}_{2} 1$ and $\mathrm{H}_{2} 2$ are soluble in common organic solvent and could be characterized by multinuclear NMR and FT-IR spectroscopic methods, by mass spectrometry and by elemental analysis (see Experimental Part for $\mathrm{H}_{2} 2$ ). The X-ray analysis of a single crystal grown by diffusion of pentane into a saturated $\mathrm{CHCl}_{3}$ solution of $\mathrm{H}_{2} 2$ revealed the formation of its $\mathrm{HCl}$ adduct $\left(\mathrm{H}_{3} 2^{+} \mathrm{Cl}^{-}\right)$, as depicted in Figure 1, which resulted from the reaction with traces of hydrogen chloride in chloroform when standing over a long period in the presence of air and moisture. Interestingly, only the most accessible "pendant" N2 atom was protonated, while the "central" N1 remained untouched, probably because the latter is already involved in an H-bond as a proton acceptor with one phenol ring (N1・OO2 2.671(5) $\AA$ ). In addition, the $\mathrm{O} 2-\mathrm{H}$ function also acts as a proton donor to the second phenol ring $(\mathrm{O} 1 \cdots \mathrm{O} 2$ 3.182(5) $\AA$ ). Intramolecular H-bonds between the central $\mathrm{N}$ and the phenol groups are often observed in the solid-state in related pro-ligands (see e.g. $[3,4$, 37-39]). The protonation of $\mathrm{N} 2$ and the presence of the chloride anion resulted in the formation of a H-bond intermolecular network involving $\mathrm{N} 2$ and $\mathrm{Cl} 1$ from one molecule and $\mathrm{O} 1$ from an adjacent one $\left(\mathrm{N} 2 \cdots{ }^{\circ} \mathrm{Cl} 1\right.$

3.040(4) $\AA, \mathrm{Cl1} \cdots \mathrm{O} 1$ 3.063(4) $\AA$ and N2-C11-O1 118.4(1) ${ }^{\circ}$. The absence of coordination/chelation to any metal center allowed $\mathrm{N} 1$ to adopt a nearly perfect tetrahedral geometry with all angles approaching the ideal $109.5^{\circ}$ (109.4(4)-111.1(4) ${ }^{\circ}$, see Table 1 for comparison with metal complexes). The protonation of $\mathrm{N} 2$ and the H-bond network induced a slightly more important distortion of the tetrahedral geometry, with angles around $\mathrm{N} 2$ ranging from $110.4(4)^{\circ}$ to $114.1(4)^{\circ}$. Noteworthy, the $\mathrm{H}_{3} 2^{+} \mathrm{Cl}^{-}$adduct is a unique example of structurally characterized $\mathrm{HCl}$ adduct for the diamino-bis(phenol) ligand family. 
<smiles>CC(C)(C)c1cc(CN(Cc2ccccn2)Cc2cc(C(C)(C)C)cc(C(C)(C)C)c2O)c(O)c(C(C)(C)C)c1</smiles>

$\mathrm{H}_{2} 1$<smiles>CN(C)CCCN(Cc1cc(C(C)(C)C)ccc1O)Cc1cc(C(C)(C)C)ccc1O</smiles>

$\mathrm{H}_{2} 2$

Scheme 2. Pro-ligand $\mathrm{H}_{2} 1$ and $\mathrm{H}_{2} 2$.

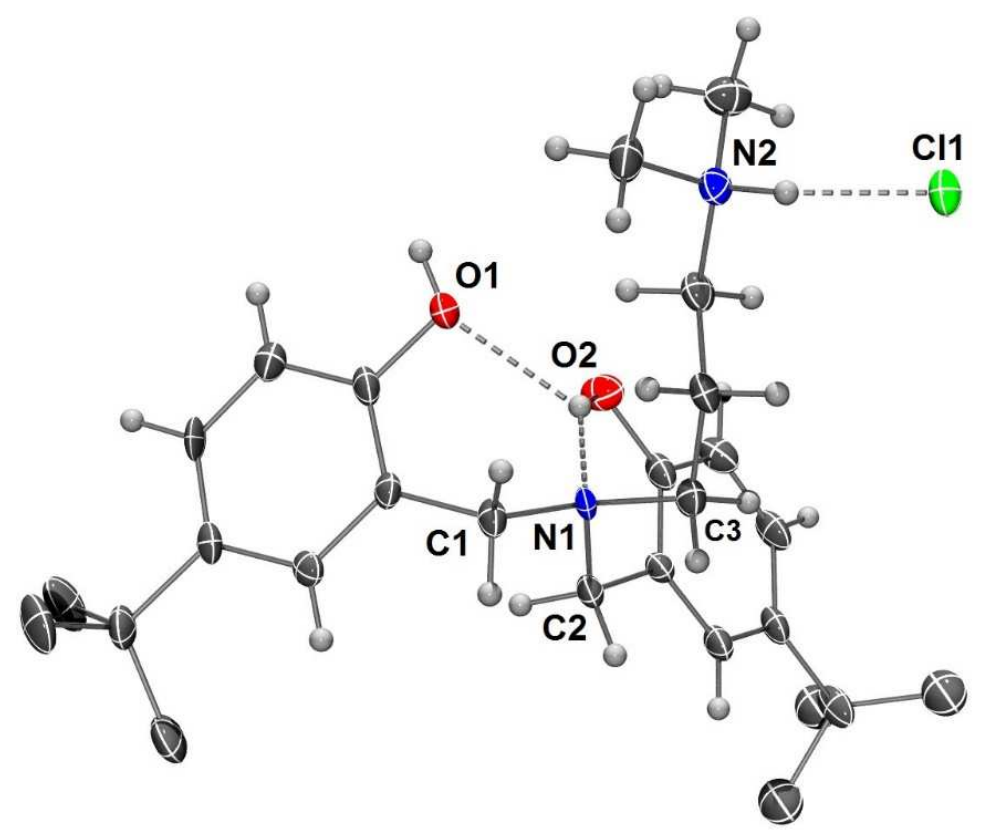

Figure 1. View of the molecular structure of $2 \cdot \mathrm{H}_{3} \mathrm{Cl}$. Hydrogen atoms of the ${ }^{t} \mathrm{Bu}$ groups omitted for clarity. Ellipsoids are represented at the 30\% probability level. Selected bond lengths ( $\AA$ ) and angles (deg): N1-C1 1.478(6), N1-C2 1.478(6), N1-C3 1.493(6), N1-O2 2.671(6), N2-C11 3.039(5), C1-N1-C2 109.9(4), C1N1-C3 111.1(4), C2-N1-C3 109.2(4).

The iron(III) complexes 3 and $\mathbf{4}$ were obtained in moderate yields (46-52\%) following a very straightforward method (Scheme 3). In air, solid $\left[\mathrm{Fe}(\mathrm{acac})_{3}\right]$ was added in one portion to a tepid $\mathrm{MeOH}$ solution of the corresponding pro-ligand and excess $\mathrm{NEt}_{3}$. After refluxing overnight, the mixture is simply filtered while hot and the pure complexes crystallized after standing at room temperature for a week. A second crop of crystals is generally possible and increases the yields by $10-20 \%$. The purity of the compounds was verified by elemental analysis. For each complex, the most intense peak in the ESI mass spectrum corresponds to $[\mathrm{M}+\mathrm{Na}]^{+}$, with the expected isotopic distribution. The solid-state molecular 
structures of complexes 3 and 4, determined by single-crystal X-ray diffraction, are depicted in Figure 2 and Figure 3, respectively. In both structures, the $\mathrm{Fe}^{\mathrm{III}}$ center is six-coordinated in a slightly distorted octahedral environment composed of one diamino-bis(phenolate) ligand, acting as tetradentate dianionic $\kappa^{4}-\left(O_{2}, N_{2}\right)$ ligand, and one chelating acac ligand (see Table 1 for selected bond lengths and angles). However, the ligand arrangement is very different in the two structures; while the two phenolate $\mathrm{O}$ donor atoms occupy relative cis positions in $\mathbf{3}$, they are trans to each other in $\mathbf{4}$. The two nitrogen donor atoms in both structures are cis, although the spacer in ligand $\mathbf{2}$ (complex 4 ) is longer. Consequently, both $\mathrm{N}$ donor atoms are trans to acac $\mathrm{O}$ donor atoms in $\mathbf{4}$, a contrario to $\mathbf{3}$ in which one is trans to one $\mathrm{O}_{\text {acac }}$ and one $\mathrm{O}_{\text {phenol }}$ (Scheme 3, Figure 2 and Figure 3). The three independent molecules that compose the crystallographic unit cell of complex $\mathbf{3}$, and the two that compose this of $\mathbf{4}$, exhibit the same features as those detailed above and depicted in Figure 2 and Figure 3. To the best of our knowledge, complex 4 represents a unique example of $\left(\mathrm{O}_{2}, \mathrm{~N}_{2}\right)$-Fe(acac) complex of such diamino-bis(phenolate) ligand in which the phenolate ligands are trans to each other (for other examples of $\left(\mathrm{O}_{2}, \mathrm{~N}_{2}\right)-\mathrm{Fe}$ (acac) complexes, with $\mathrm{O}=$ phenolate and $\mathrm{N}=$ amine, see $[4,40])$. One might be tempted to attribute these structural divergences to differences in steric congestion around the iron center upon coordination, because of the presence/absence of ortho ${ }^{t} \mathrm{Bu}$ groups on the phenol rings. However, this hypothesis is ruled out by the observation of an opposite trend for cobalt (see below). The difference in spacer nature and length between the two $\mathrm{N}$ donors in 3 and 4 leads to a much more smaller N-Fe-N bite-angle in 3 than in $4\left(76.76(11)^{\circ}\right.$ and $98.80(17)^{\circ}$, respectively). The Fe- $\mathrm{O}_{\text {phenol }}$ bond lengths (1.868(3)-1.931(4) $\AA$ ) in $\mathbf{3}$ and $\mathbf{4}$ are significantly shorter than the Fe-O $\mathrm{O}_{\text {acac }}$ bond lengths (1.960(3)-2.068(3) $\AA$ ); while in 4 both are in the same range (1.995(4)-2.051(4) $\AA)$, in 3 the $\mathrm{Fe}-\mathrm{O}_{\text {acac }}$ bond trans to the phenolate ligand is significantly longer than the one trans to the amine (2.055(4)-2.068(3) ̊ vs. 1.960(3)-1.971(3) ̊). The nature of the N pendant donor group, i.e. pyridine or $\mathrm{NMe}_{2}$, slightly influenced the corresponding Fe-N bond lengths, since those in 3 (py: 2.192(3)-2.207(4) $\AA$ ) are slightly shorter than those in 4 ( $\left.\mathrm{NMe}_{2}: 2.226(4)-2.244(5) \AA\right)$. The tetrahedral geometry around the central $\mathrm{N}$ atom is not strongly affected upon coordination, with angles ranging from $106.1(4)^{\circ}$ to $110.7(3)^{\circ}$ in 3 and 4. Except for the large N11-Fe1-N12 bite angle in 4, due to the unusual propyl spacer, all the other structural parameters are in line with these reported for other related diamino-bis(phenolate) $\left(\mathrm{O}_{2}, \mathrm{~N}_{2}\right)$ $\mathrm{Fe}$ (acac) complexes, which all contain a $\mathrm{C}_{2}$ spacer between the two $\mathrm{N}$ donors $\left(\mathrm{NMe}_{2}\right.$ or py) $[4,41,42]$. 
${ }^{t} \mathrm{Bu}$

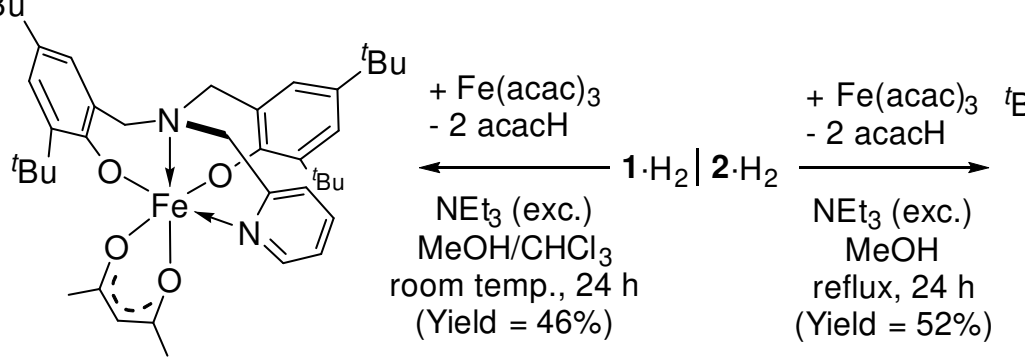

3

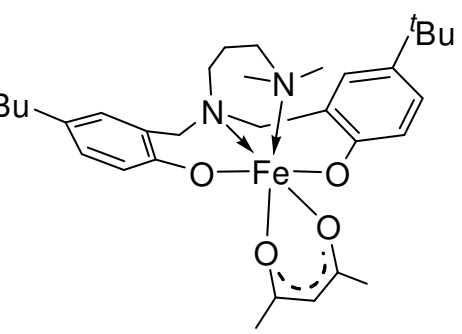

4

Scheme 3. Synthesis of the $\mathrm{Fe}^{\mathrm{III}}(\mathrm{acac})$ complexes (3-4).

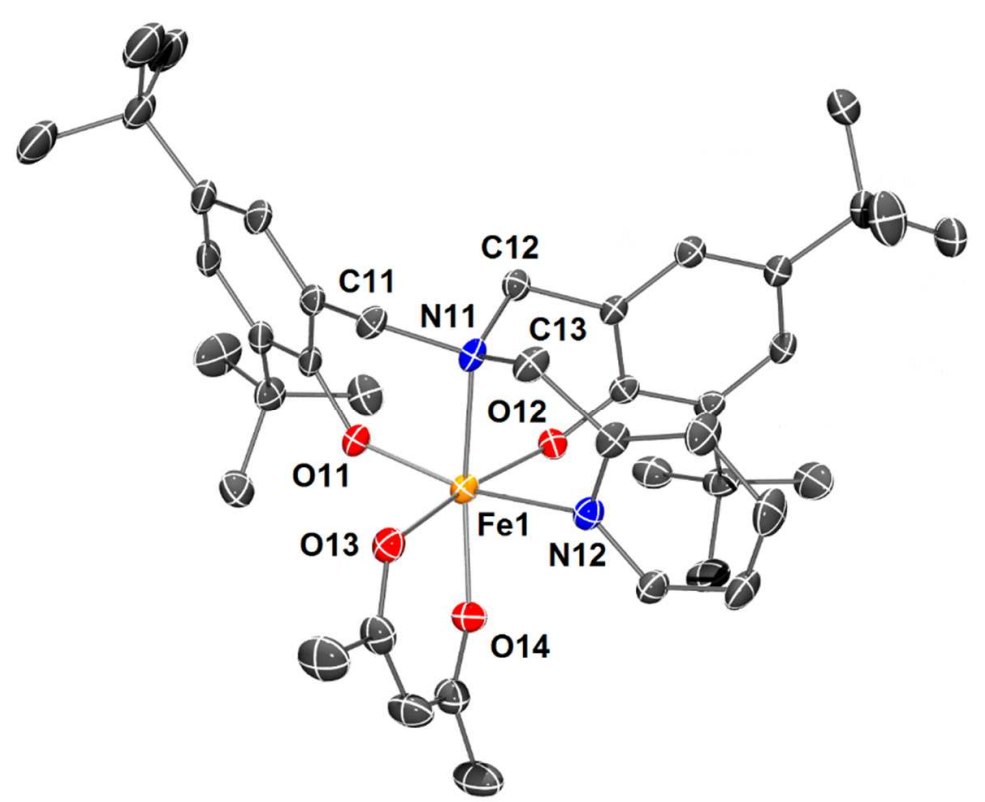

Figure 2. View of the molecular structure of 3. Only one of the three independent molecules is represented. The hydrogen atoms are omitted for clarity. Ellipsoids are represented at the 30\% probability level. Selected bond lengths ( $\AA$ ) and angles (deg) are given in Table 1. 


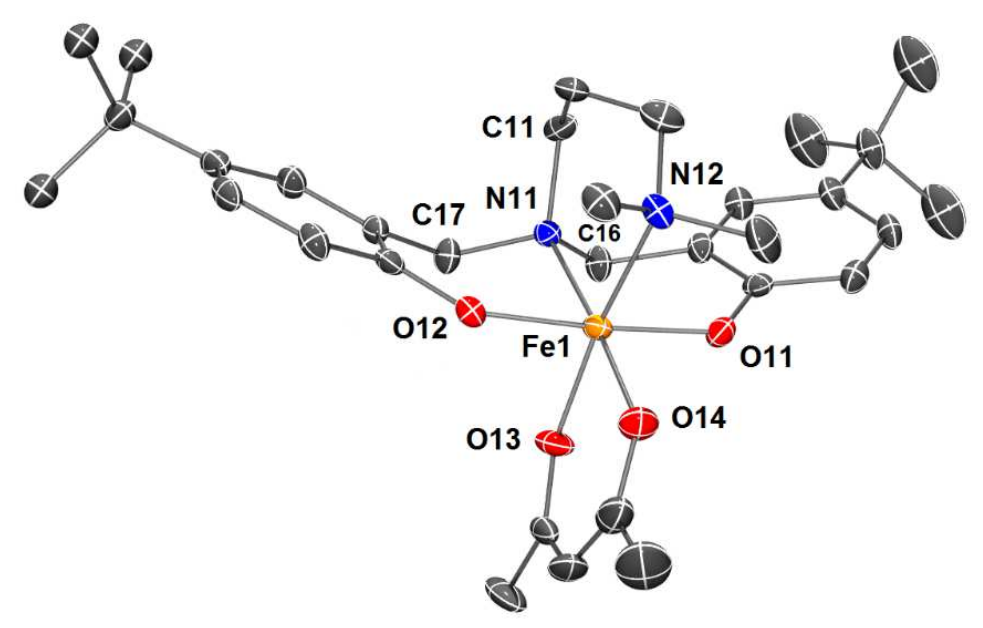

Figure 3. View of the molecular structure of $\mathbf{4}$ in $\mathbf{4} \cdot \mathrm{MeOH}$. Only one of the two independent molecules is represented. The solvent molecule and the hydrogen atoms are omitted for clarity. Ellipsoids are represented at the $30 \%$ probability level. Selected bond lengths $(\AA)$ and angles (deg) are given in Table 1 . 
Table 1. Selected bond lengths ( $\AA$ ) and angles (deg) in the solid-state structures of $\mathbf{3}, \mathbf{4} \cdot \mathrm{MeOH}, \mathbf{5}$ and $\mathbf{6}$.

\begin{tabular}{|c|c|c|c|c|}
\hline & 3 & $4 \cdot \mathrm{MeOH}$ & 5 & 6 \\
\hline $\mathrm{M} 1-\mathrm{N}(1) 1$ & $2.192(3)$ & $2.237(5)$ & $1.969(3)$ & $2.035(2)$ \\
\hline $\mathrm{M} 1-\mathrm{N}(1) 2$ & $2.198(3)$ & $2.227(5)$ & $1.917(3)$ & $2.112(2)$ \\
\hline M1-O(1)1 & $1.873(2)$ & $1.931(4)$ & $1.926(2)$ & $1.9171(18)$ \\
\hline $\mathrm{M} 1-\mathrm{O}(1) 2$ & $1.922(2)$ & $1.903(4)$ & $1.895(2)$ & $1.8967(18)$ \\
\hline M1-O(1)3 & $2.066(3)$ & $2.041(4)$ & $1.900(2)$ & $1.8976(18)$ \\
\hline $\mathrm{M} 1-\mathrm{O}(1) 4$ & $1.960(3)$ & $1.996(4)$ & $1.898(2)$ & $1.9057(18)$ \\
\hline $\mathrm{N}(1) 1-\mathrm{M} 1-\mathrm{N}(1) 2$ & $76.76(11)$ & $98.80(17)$ & $85.54(12)$ & $95.04(9)$ \\
\hline $\mathrm{N}(1) 1-\mathrm{M} 1-\mathrm{O}(1) 1$ & $86.95(11)$ & $88.38(16)$ & $95.51(10)$ & $90.75(8)$ \\
\hline $\mathrm{N}(1) 1-\mathrm{M} 1-\mathrm{O}(1) 2$ & $91.79(10)$ & $87.38(16)$ & $92.09(10)$ & $93.78(8)$ \\
\hline $\mathrm{N}(1) 1-\mathrm{M} 1-\mathrm{O}(1) 3$ & $86.09(11)$ & $89.28(16)$ & $90.27(11)$ & $89.26(9)^{d}$ \\
\hline $\mathrm{N}(1) 2-\mathrm{M} 1-\mathrm{O}(1) 4$ & $92.82(12)$ & $85.05(18)$ & $89.25(11)$ & $86.84(8)^{e}$ \\
\hline $\mathrm{C}(1) 1-\mathrm{N}(1) 1-\mathrm{C}(1) 2$ & $109.8(3)$ & $108.9(4)^{a}$ & $107.6(3)$ & $105.08(18)$ \\
\hline $\mathrm{C}(1) 1-\mathrm{N}(1) 1-\mathrm{C}(1) 3$ & $108.7(3)$ & $110.1(4)^{b}$ & $110.0(3)$ & $106.70(19)$ \\
\hline $\mathrm{C}(1) 2-\mathrm{N}(1) 1-\mathrm{C}(1) 3$ & $110.7(3)$ & $106.2(4)^{c}$ & $110.2(3)$ & $108.21(19)$ \\
\hline
\end{tabular}

$\overline{{ }^{a} \mathrm{C} 11-\mathrm{N} 11-\mathrm{C} 16 \text { for } \mathbf{4},{ }^{b} \mathrm{C} 11-\mathrm{N} 11-\mathrm{C} 17 \text { for } \mathbf{4},{ }^{c} \mathrm{C} 16-\mathrm{N} 11-\mathrm{C} 17 \text { for } \mathbf{4},{ }^{d} \mathrm{~N} 2-\mathrm{Co} 1-\mathrm{O} 3 \text { for } \mathbf{6},{ }^{e} \mathrm{~N} 2-\mathrm{Co} 1-\mathrm{O} 4 \text { for } \mathbf{6} .}$

The cobalt(III) complexes 5 and $\mathbf{6}$ were obtained in moderate yields (52-54\%) following the same straightforward method as for their iron(III) analogs (see above). Again, these yields may be slightly improved by repetitive crystallizations (each over several days/weeks) of the mother liquor (up to 65-70\%, Scheme 4). Complexes 5 and $\mathbf{6}$ were characterized by EA, FT-IR and ESI-MS (see Experimental Part). As expected, the low-spin $\mathrm{Co}^{\mathrm{III}}$ complexes 5 and $\mathbf{6}$ are diamagnetic ( $\mathrm{d}^{6}$ metal ion) and their ${ }^{1} \mathrm{H}$ NMR spectra support the proposed structures. Notably, in each compound the two Me groups from the acac ligand gave rise to distinct resonances, as already observed for other $\left(\mathrm{O}_{2}, \mathrm{~N}_{2}\right)$-Co(acac) complexes [43, 44], confirming that the structure is retained in solution. The solid-state molecular structures of complexes $\mathbf{5}$ and $\mathbf{6}$, established by single-crystal X-ray diffraction, are depicted in Figure 4 and Figure 5, respectively. The $\mathrm{Co}^{\mathrm{III}}$ metal center of both complexes is found in a slightly distorted octahedral environment, which is composed of one dianionic $\kappa^{4}-\left(\mathrm{O}_{2}, \mathrm{~N}_{2}\right)$ diamino-bis(phenolate) ligand and one chelating acac ligand (see Table 1 for selected bond lengths and angles). Similarly to their $\mathrm{Fe}^{\mathrm{III}}$ analogues $(\mathbf{3 - 4}$, see above) the arrangement of the 
ligands around the metal center differs in $\mathbf{5}$ and $\mathbf{6}$, since the phenolates of ligand $\mathbf{1}$ are found trans to each other in $\mathbf{5}$, while those of ligand $\mathbf{2}$ are cis in $\mathbf{6}$. However, the trend is opposite to what is observed in $\mathbf{3}$ (cisphenolates of 1) and 4 (trans-phenolates of 2). The second independent molecules that compose the crystallographic unit cell of complex $\mathbf{5}$ exhibit the same features that those detailed above and depicted in Figure 4. Although complexes 5 and $\mathbf{6}$ are unique examples of $\left(\mathrm{O}_{2}, \mathrm{~N}_{2}\right) \mathrm{Co}(\mathrm{acac})$ complexes of diaminobis(phenolate) ligands of that type, their structural parameters can be compared to a related complex in which the acac ligand is replaced by curcumin, another $\beta$-diketonato ligand [45]. While the Co- $\mathrm{O}_{\text {phenol }}$ bond lengths were found in the same range for the three complexes (1.895(2)-1.926(2) $\AA$ ), the Co-Oacac bond lengths in $\mathbf{5}$ and $\mathbf{6}$, which are very similar (1.898(2)-1.906(2) $\AA$ ), are slightly longer than those in the curcumin derivative (1.877(4)-1.880(4) $\AA$ ). For comparison, the $\mathrm{Co}-\mathrm{O}_{\text {acac }}$ bond lengths in $\mathrm{Co}(\mathrm{acac})_{3}$ are found in the range 1.875(2)-1.889(2) $\AA$ [46], which are typical values for $\mathrm{Co}^{\mathrm{III}}$ (acac) complexes, while Co$\mathrm{O}_{\text {acac }}$ bond lengths in $\mathrm{Co}^{\mathrm{II}}$ complexes are significantly longer (av. $2.06 \AA$ ). The $\mathrm{M}-\mathrm{O}$ and $\mathrm{M}-\mathrm{N}$ bonds are generally shorter in the $\mathrm{Co}^{\mathrm{III}}$ complexes than in their $\mathrm{Fe}^{\mathrm{III}}$ analogues, which can be attributed to the slightly smaller atomic radius of the former. However, the Co- $\mathrm{N}_{\mathrm{py}}$ bond length in complex $\mathbf{5}$ is shorter (1.917(3) $\mathrm{A}$ ) than the Co- $\mathrm{N}_{\mathrm{NMe} 2}$ bond length in 6 or in the curcumin derivative (2.112(2) and 1.956(5) $\AA$, respectively) and notably also much shorter that the Fe- $\mathrm{N}_{\mathrm{py}}$ distance in 3 (2.198(3) $⿱$ ). While the difference between 5 and 6 may be attributed to the nature of the $\mathrm{N}$ atom itself, $\mathrm{sp}^{2}$ in the pyridine cycle and $\mathrm{sp}^{3}$ in the amine group, the even larger difference between $\mathbf{5}$ and $\mathbf{3}$ would originate from the influence of the ligand trans to the $\mathrm{N}_{\text {py }}$ atom $\left(\mathrm{O}_{\text {phenolate }}\right.$ in $\mathbf{3} v s$. $\mathrm{O}_{\text {acac }}$ in $\mathbf{5}$ ). No steric congestion or packing effect can be easily invoked as being responsible for this unusually short bond.
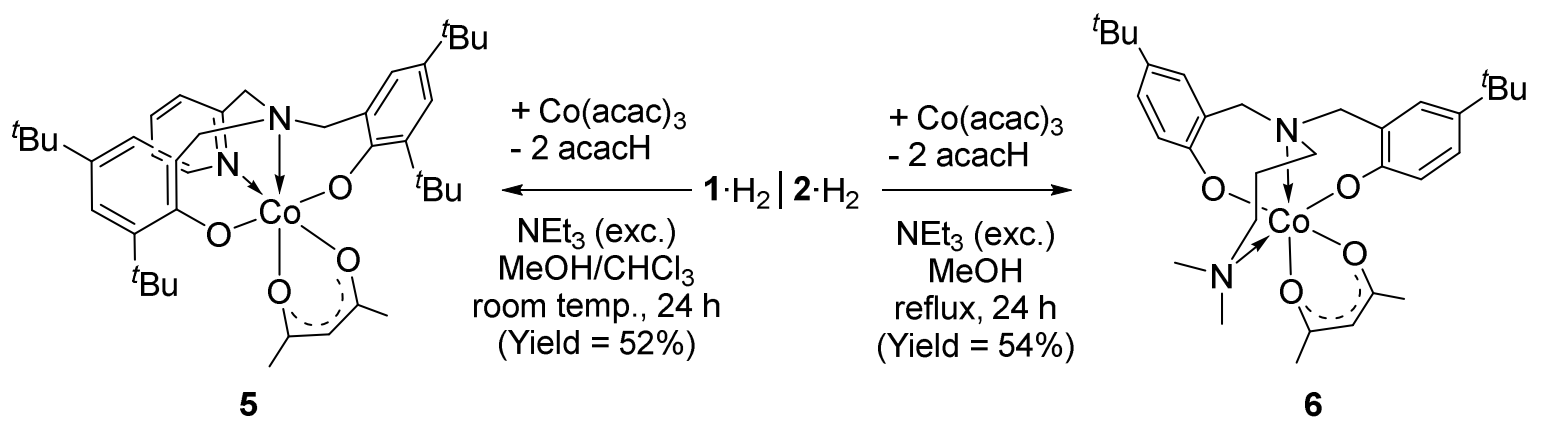

Scheme 4. Synthesis of the Co ${ }^{\text {III }}(\mathrm{acac})$ complexes (5-6). 


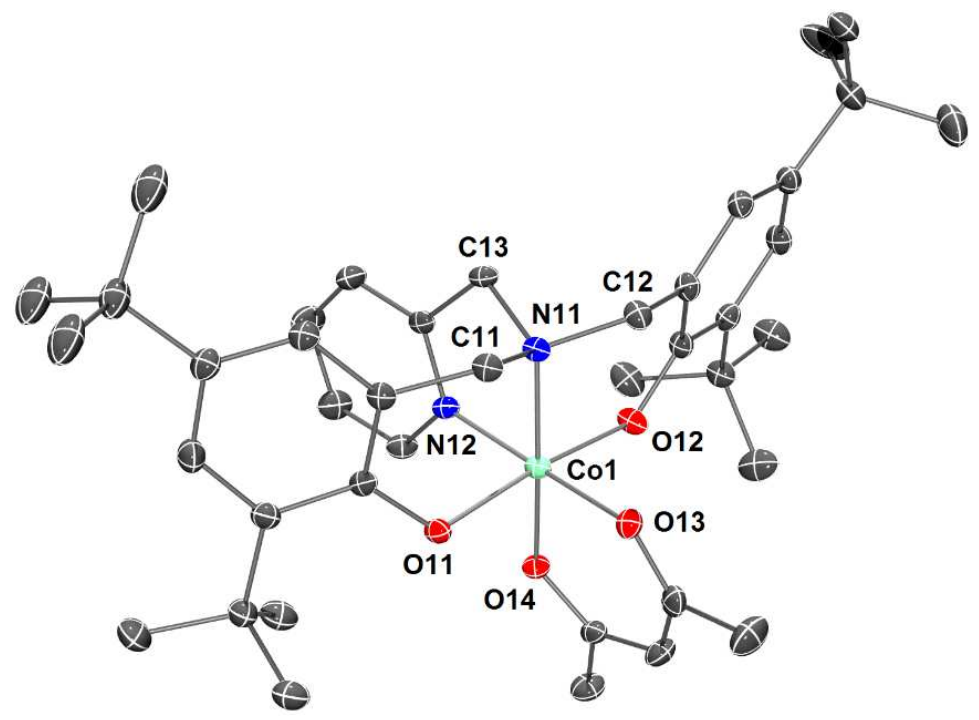

Figure 4. View of the molecular structure of 5. Only one of the two independent molecules is represented. The hydrogen atoms are omitted for clarity. Ellipsoids are represented at the 30\% probability level. Selected bond lengths $(\AA)$ and angles (deg) are given in Table 1 .

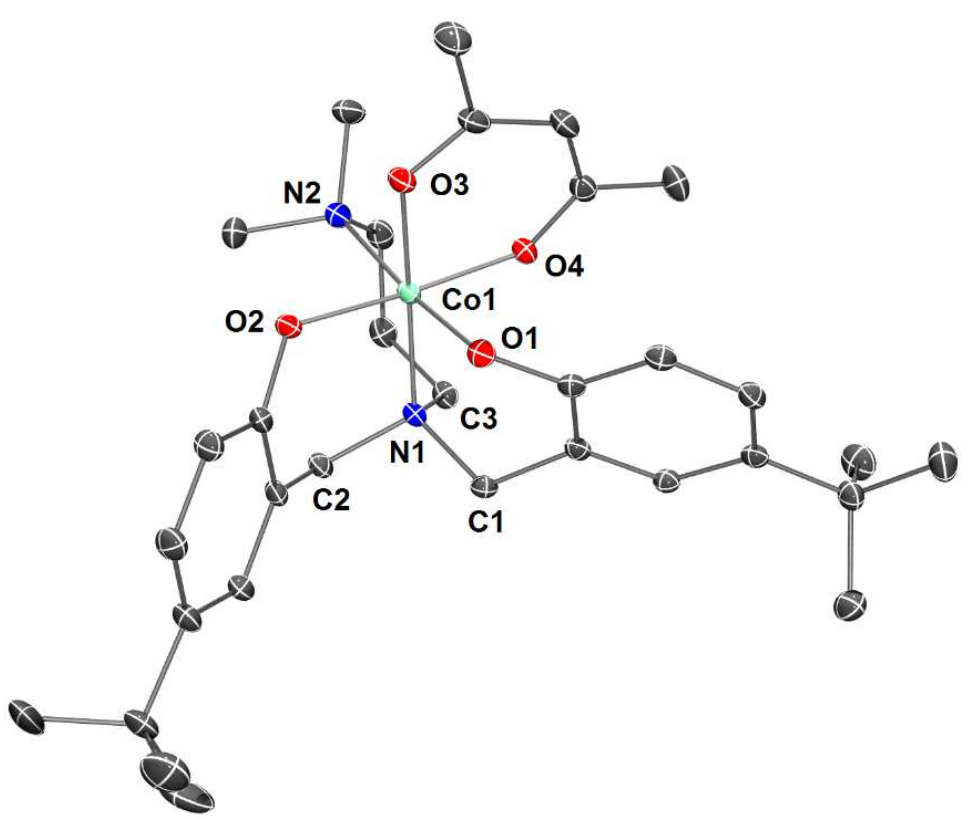

Figure 5. View of the molecular structure of $\mathbf{6}$. The hydrogen atoms are omitted for clarity. Ellipsoids are represented at the $30 \%$ probability level. Selected bond lengths $(\AA)$ and angles (deg) are given in Table 1 . 
As stated in the introduction, one motivation for carrying out this work was to probe the potential of new $\mathrm{Fe}^{\mathrm{III}}$ and $\mathrm{Co}^{\mathrm{III}}$ complexes as radical initiators and controlling agents in the OMRP protocol. In the early 80 's, the potential of a Salen-Co ${ }^{\text {III }}$ (acac) [Salen $=N, N^{\prime}$-ethylenebis(salicylideneiminato)] complex to produce an acac radical, able to initiate the radical polymerization of methyl methacrylate, was mentioned by Kalpagam and coworkers [30]. The authors were able to polymerize methyl methacrylate (MMA), via the thermal activation of the Co-acac bond (reactions performed in benzene, at 60 or $70^{\circ} \mathrm{C}$, at various [Co] and [MMA]), whereas no polymerization took place for acrylonitrile, styrene, or vinyl acetate. The polymerization was proposed to follow a free-radical mechanism, in contrast to a controlled radical polymerization. The monomer selectivity led the authors to suggest monomer coordination prior to decomposition/radical formation and polymerization. It can be mentioned that a $\mathrm{Co}^{\mathrm{II}}$ complex of a Salen derivative, in combination with AIBN as radical source, mediates the OMRP of VAc at $60{ }^{\circ} \mathrm{C}$ (bulk conditions: $\left.\left[\mathrm{Co}{ }^{\mathrm{II}}\right]_{0} /[\mathrm{AIBN}]_{0} /[\mathrm{VAc}]_{0}=1 / 3 / 700\right)[47]$.

With this background, we tested complexes 3-6 as thermal initiators for the (controlled) polymerization of MMA, VAc or tBA. As starting point, the reactivity of both iron and cobalt complexes towards MMA was studied in the conditions that allowed MMA polymerization with the Salen-Co ${ }^{\text {III }}$ (acac) complex (see Exp. Part) [30], but no monomer consumption was observed (NMR evidence) after $3 \mathrm{~h}$ at $70{ }^{\circ} \mathrm{C}$. The two other monomers (VAc and $\mathrm{tBA}$ ) were selected because they also contain $\mathrm{O}$ atoms that may interact with the metal center and render the acac ligand more labile, favoring the radical formation as suggested by Kalpagam and coworkers (see above). Similar reaction conditions as those studied for MMA were applied to VAc, and even after prolonged reaction time $\left(18 \mathrm{~h}\right.$ at $\left.70{ }^{\circ} \mathrm{C}\right)$ no PVAc was formed. Finally, an attempt to initiate the radical polymerization $\mathrm{BAA}$, a reactive radical, was realized in bulk conditions (no solvent) and with a much higher concentration of potential radical initiator $\left([4]_{0} /[\mathrm{tBA}]_{0}=1 / 760\right.$ vs. $\left.\approx 1 / 8.10^{4}\right)$. However, no polymerization reaction was observed upon heating this mixture at temperatures ranging from 90 to $130{ }^{\circ} \mathrm{C}$ for $1-3 \mathrm{~h}$ (sealed tube).

\section{Conclusion}

The synthesis of four $\left[\kappa^{4}-\left(N_{2}, O_{2}\right) \mathrm{M}(\mathrm{acac})\right]$ complexes $(\mathrm{M}=\mathrm{Fe}$ and $\mathrm{Co})$ with two tetradentate diaminobis(phenolate) ligands has been reported. All of them were characterized in the solid-state by X-ray diffraction analysis. Within this series, the Co derivatives represent the first examples of $\left(\mathrm{O}_{2}, \mathrm{~N}_{2}\right) \mathrm{Co}$ (acac) complexes of diamino-bis(phenolate) ligands. Although the already reported ligand $\mathrm{H}_{2} \mathbf{1}$ and the newly synthesized ligand $\mathrm{H}_{2} 2$ are very similar, the arrangement of their donor atoms around both iron and cobalt differs and simple steric factors do not appear able to explain this observation. These complexes were designed and synthesized with the objective to use them as single-component initiators/moderators for 
radical polymerization. However, the metal-acac chelate did not produce radicals under the thermal conditions used in the present study. We are now exploring other catalytic applications for these complexes, because the use of air-stable and earth-abundant metal catalysts for chemical transformations remains of interest. 
Table 2. Crystallographic data for compounds $\mathrm{H}_{3} \mathbf{2}^{+} \mathrm{Cl}^{-}, \mathbf{3}$ and $\mathbf{4} \cdot \mathrm{MeOH}$.

\begin{tabular}{|c|c|c|c|}
\hline Compound & $\mathrm{H}_{3} 2^{+} \mathrm{Cl}^{-}$ & 3 & 4. $\mathrm{MeOH}$ \\
\hline CCDC number & 1851284 & 1851285 & 1851286 \\
\hline Empirical formula & $\left(\mathrm{C}_{27} \mathrm{H}_{43} \mathrm{~N}_{2} \mathrm{O}_{2}\right) \mathrm{Cl}$ & $\left(\mathrm{C}_{41} \mathrm{H}_{57} \mathrm{FeN}_{2} \mathrm{O}_{4}\right) 3$ & $\left(\mathrm{C}_{32} \mathrm{H}_{47} \mathrm{FeN}_{2} \mathrm{O}_{4}, \mathrm{CH}_{4} \mathrm{O}\right)_{2}$ \\
\hline Formula weight & 463.08 & 2093.20 & 611.60 \\
\hline Temperature, $\mathrm{K}$ & $173(2)$ & $173(2)$ & $173(2)$ \\
\hline Wavelength, $\AA$ & 0.71073 & 0.71073 & 0.71073 \\
\hline Crystal system & Monoclinic & Triclinic & Orthorhombic \\
\hline Space group & $\mathrm{P} 2{ }_{1} / \mathrm{n}$ & $\mathrm{P}-1$ & $\mathrm{P} 2{ }_{1} 2_{1} 2_{1}$ \\
\hline $\mathrm{a}, \AA$ & $6.2965(16)$ & $14.7847(10)$ & $13.5447(4)$ \\
\hline $\mathrm{b}, \AA$ & $36.678(8)$ & $21.5856(13)$ & $22.4938(8)$ \\
\hline $\mathrm{c}, \AA$ & $11.952(3)$ & $22.2157(14)$ & $22.6633(7)$ \\
\hline$\alpha,{ }^{\circ}$ & 909.0 & $67.899(3)$ & 90.0 \\
\hline$\beta,{ }^{\circ}$ & $101.113(7)$ & $71.325(3)$ & 90.0 \\
\hline$\gamma,{ }^{\circ}$ & 90.0 & $89.035(4)$ & 90.0 \\
\hline Volume, $\AA^{3}$ & $2708.4(11)$ & $6179.5(7)$ & $6904.9(4)$ \\
\hline $\mathrm{Z}$ & 4 & 2 & 4 \\
\hline Density (calc), $\mathrm{Mg} / \mathrm{m}^{3}$ & 1.136 & 1.125 & 1.177 \\
\hline Abs. coefficient, $\mathrm{mm}^{-1}$ & 0.165 & 0.405 & 0.475 \\
\hline $\mathrm{F}(000)$ & 1008 & 2250 & 2632 \\
\hline Crystal size, $\mathrm{mm}^{3}$ & $0.41 \times 0.33 \times 0.11$ & $0.24 \times 0.08 \times 0.06$ & $0.28 \times 0.23 \times 0.18$ \\
\hline Theta range, ${ }^{\circ}$ & 2.820 to 24.858 & 1.025 to 26.37 & 2.962 to 26.372 \\
\hline Reflections collected & 11160 & 185444 & 38693 \\
\hline Indpt reflections $\left(\mathrm{R}_{\text {int }}\right)$ & $4353(0.0707)$ & $25065(0.121)$ & $14029(0.0641)$ \\
\hline Completeness, $\%$ & 91.0 & 99.2 & 99.5 \\
\hline Absorption correction & Multi-scan & Multi-scan & Multi-scan \\
\hline Max. / min. transmission & 0.7451 and 0.6049 & 0.7454 and 0.6424 & 1.0 and 0.843 \\
\hline Refinement method & $\mathrm{F}^{2}$ & $F^{2}$ & $F^{2}$ \\
\hline Data /restraints/parameters & $4353 / 18 / 295$ & 25065 / 60 / 1321 & 14029 / 27 / 747 \\
\hline Goodness-of-fit on $\mathrm{F}^{2}$ & 1.026 & 1.044 & 1.017 \\
\hline $\mathrm{R} 1, \mathrm{wR} 2[\mathrm{I}>2 \sigma(\mathrm{I})]$ & $0.0818,0.1798$ & $0.0656,0.1494$ & $0.0579,0.1191$ \\
\hline R1, wR2 (all data) & $0.1647,0.2141$ & $0.1267,0.1824$ & $0.0983,0.1397$ \\
\hline Absolute structure & & & $-0.018(10)$ \\
\hline Residual density, e. $\AA^{-3}$ & $0.398 /-0.309$ & $0.776 /-0.617$ & $0.548 /-0.374$ \\
\hline
\end{tabular}


Table 3. Crystallographic data for compounds 5 and 6.

\begin{tabular}{|c|c|c|}
\hline Compound & 5 & 6 \\
\hline CCDC number & 1851287 & 1851288 \\
\hline Empirical formula & $\left(\mathrm{C}_{41} \mathrm{H}_{57} \mathrm{CoN}_{2} \mathrm{O}_{4}\right)_{2}$ & $\mathrm{C}_{32} \mathrm{H}_{47} \mathrm{CoN}_{2} \mathrm{O}_{4}$ \\
\hline Formula weight & 1401.63 & 582.64 \\
\hline Temperature, $\mathrm{K}$ & $173(2)$ & $173(2)$ \\
\hline Wavelength, $\AA$ & 0.71073 & 0.71073 \\
\hline Crystal system & Monoclinic & Monoclinic \\
\hline Space group & $\mathrm{C} 2 / \mathrm{c}$ & $\mathrm{P} 2{ }_{1} / \mathrm{n}$ \\
\hline $\mathrm{a}, \AA$ & $25.0226(14)$ & $14.9490(8)$ \\
\hline $\mathrm{b}, \AA$ & $15.2692(8)$ & $13.6980(8)$ \\
\hline $\mathrm{c}, \AA$ & $42.694(3)$ & $17.6310(10)$ \\
\hline$\alpha, \circ$ & 90.0 & 90.0 \\
\hline$\beta,{ }^{\circ}$ & $101.398(2)$ & 97.50 \\
\hline$\gamma,{ }^{\circ}$ & 90.0 & 90.0 \\
\hline Volume, $\AA^{3}$ & $15990.5(16)$ & $3579.4(3)$ \\
\hline $\mathrm{Z}$ & 8 & 4 \\
\hline Density (calc), $\mathrm{Mg} / \mathrm{m}^{3}$ & 1.164 & 1.081 \\
\hline Abs. coefficient, $\mathrm{mm}^{-1}$ & 0.469 & 0.511 \\
\hline $\mathrm{F}(000)$ & 6016 & 1248 \\
\hline Crystal size, $\mathrm{mm}^{3}$ & $0.37 \times 0.10 \times 0.05$ & $0.50 \times 0.13 \times 0.12$ \\
\hline Theta range, ${ }^{\circ}$ & 2.254 to 25.027 & 2.749 to 26.371 \\
\hline Reflections collected & 79537 & 63727 \\
\hline Indpt reflections $\left(\mathrm{R}_{\text {int }}\right)$ & $14121(0.072)$ & $7310(0.0599)$ \\
\hline Completeness, $\%$ & 99.9 & 99.8 \\
\hline Absorption correction & Multi-scan & Multi-scan \\
\hline Max. / min. transmission & 0.7454 and 0.6788 & 0.7479 and 0.5996 \\
\hline Refinement method & $F^{2}$ & $\mathrm{~F}^{2}$ \\
\hline Data/restraints/parameters & $14121 / 30 / 881$ & $7310 / 0 / 362$ \\
\hline Goodness-of-fit on $\mathrm{F}^{2}$ & 1.169 & 1.078 \\
\hline $\mathrm{R} 1, w \mathrm{R} 2[\mathrm{I}>2 \sigma(\mathrm{I})]$ & $0.0633,0.1174$ & $0.0502,0.1516$ \\
\hline R1, wR2 (all data) & $0.0962,0.1300$ & $0.0645,0.1619$ \\
\hline Residual density, e. $\AA^{-3}$ & $0.519 /-0.705$ & $0.766 /-0.317$ \\
\hline
\end{tabular}




\section{Conflict of interest}

The authors declare no conflict of interest.

\section{Appendix A. Supplementary data}

CCDC 1851284 - 1851288 contains the supplementary crystallographic data for $\mathrm{H}_{3} \mathbf{2}^{+} \mathrm{Cl}^{-} \cdot \mathbf{3}, \mathbf{4} \cdot \mathrm{MeOH}, \mathbf{5}, \mathbf{6}$. These data can be obtained free of charge via http://www.ccdc.cam.ac.uk/conts/retrieving.html, or from the Cambridge Crystallographic Data Centre, 12 Union Road, Cambridge CB2 1EZ, UK; fax: (+44) 1223-336033; or e-mail: deposit@ccdc.cam.ac.uk.

\section{Acknowledgments}

The authors thank the Agence Nationale de la Recherche (Grant ANR-14-CE07-0012, FLUPOL) for support of this work. Additional support by the Ministère de l'Enseignement Supérieur et de la Recherche Scientifique (MESRS, PROFAS B+ fellowship to Y.K.R and Ph.D. fellowship to L.T.), the Centre National de la Recherche Scientifique (CNRS) and the Institut Universitaire de France (IUF) are also gratefully acknowledged.

\section{References}

[1] C.J. Hinshaw, G. Peng, R. Singh, J.T. Spence, J.H. Enemark, M. Bruck, J. Kristofzski, S.L. Merbs, R.B. Ortega, P.A. Wexler, Inorg. Chem., 28 (1989) 4483-4491.

[2] O. Wichmann, R. Sillanpää, A. Lehtonen, Coord. Chem. Rev., 256 (2012) 371-392.

[3] A.K. Bowser, A.M. Anderson-Wile, D.H. Johnston, B.M. Wile, Appl. Organomet. Chem., 30 (2016) 32-39.

[4] K. Hasan, L.N. Dawe, C.M. Kozak, Eur. J. Inorg. Chem., 2011 (2011) 4610-4621.

[5] M. Taherimehr, J.P. Serta, A.W. Kleij, C.J. Whiteoak, P.P. Pescarmona, ChemSusChem, 8 (2015) 10341042.

[6] L.N. Saunders, N. Ikpo, C.F. Petten, U.K. Das, L.N. Dawe, C.M. Kozak, F.M. Kerton, Catal. Commun., 18 (2012) 165-167.

[7] L.E.N. Allan, M.R. Perry, M.P. Shaver, Prog. Polym. Sci., 37 (2012) 127-156.

[8] R. Poli, Eur. J. Inorg. Chem., (2011) 1513-1530.

[9] M. Hurtgen, C. Detrembleur, C. Jerome, A. Debuigne, Polymer Reviews, 51 (2011) 188-213.

[10] R. Poli, Angew. Chem. Int. Ed., 45 (2006) 5058-5070.

[11] A. Debuigne, R. Poli, C. Jerome, R. Jerome, C. Detrembleur, Prog. Polym. Sci., 34 (2009) 211-239.

[12] A. Debuigne, C. Jérôme, C. Detrembleur, Polymer, 115 (2017) 285-307.

[13] E.V. Bellan, L. Thevenin, F. Gayet, C. Fliedel, R. Poli, ACS Macro Lett., 6 (2017) 959-962.

[14] Z.G. Xue, R. Poli, J. Polym. Sci., Part A: Polym. Chem., 51 (2013) 3494-3504.

[15] Y. Champouret, K.C. MacLeod, K.M. Smith, B.O. Patrick, R. Poli, Organometallics, 29 (2010) 31253132 . 
[16] Y. Champouret, K.C. MacLeod, U. Baisch, B.O. Patrick, K.M. Smith, R. Poli, Organometallics, 29 (2010) 167-176.

[17] K.K.S. Santhosh, Y.G. Li, Y. Gnanou, U. Baisch, Y. Champouret, R. Poli, K.C.D. Robson, W.S. McNeil, Chem. Asian J., 4 (2009) 1257-1265.

[18] K. Santhosh, Y. Gnanou, Y. Champouret, J.C. Daran, R. Poli, Chem. Eur. J., 15 (2009) 4874-4885.

[19] A. Debuigne, Y. Champouret, R. Jerome, R. Poli, C. Detrembleur, Chem. Eur. J., 14 (2008) 40464059.

[20] Y. Champouret, U. Baisch, R. Poli, L. Tang, J.L. Conway, K.M. Smith, Angew. Chem. Int. Ed., 47 (2008) 6069-6072.

[21] S. Maria, H. Kaneyoshi, K. Matyjaszewski, R. Poli, Chem. Eur. J., 13 (2007) 2480-2492.

[22] R. Poli, Chem. Eur. J., 21 (2015) 6988-7001.

[23] T.G. Ribelli, S.M. Wahidur Rahaman, J.-C. Daran, P. Krys, K. Matyjaszewski, R. Poli, Macromolecules, 49 (2016) 7749-7757.

[24] S. Banerjee, V. Ladmiral, A. Debuigne, C. Detrembleur, R. Poli, B.M. Ameduri, Angew. Chem. Int. Ed., 57 (2018) 2934-2937.

[25] R. Poli, L.E.N. Allan, M.P. Shaver, Prog. Polym. Sci., 39 (2014) 1827-1845.

[26] L.E.N. Allan, J.P. MacDonald, G.S. Nichol, M.P. Shaver, Macromolecules, 47 (2014) 1249-1257.

[27] R. Poli, M.P. Shaver, Inorg. Chem., 53 (2014) 7580-7590.

[28] D.L. Coward, B.R.M. Lake, M.P. Shaver, Organometallics, 36 (2017) 3322-3328.

[29] J. Demarteau, A. Kermagoret, I. German, D. Cordella, K. Robeyns, J. De Winter, P. Gerbaux, C. Jérôme, A. Debuigne, C. Detrembleur, Chem. Commun., 51 (2015) 14334-14337.

[30] R. Thiagarajan, V. Kalpagam, U.S. Nandi, J. Polym. Sci., Part A: Polym. Chem., 20 (1982) 675-681.

[31] E.M. Arnett, M.A. Mendelsohn, J. Am. Chem. Soc., 84 (1962) 3821-3824.

[32] G.M. Sheldrick, Acta Crystallogr. Sect. A: Found. Crystallogr., A71 (2015) 3-8.

[33] G.M. Sheldrick, Acta Crystallogr. Sect. C: Cryst. Struct. Commun., C71 (2015) 3-8.

[34] A.L. Spek, J. Appl. Crystallogr., 36 (2003) 7-13.

[35] H.D. Flack, Acta Crystallogr. Sect. A: Found. Crystallogr., A39 (1983) 876-881.

[36] Y. Shimazaki, S. Huth, A. Odani, O. Yamauchi, Angew. Chem. Int. Ed., 39 (2000) 1666-1669.

[37] H. Schroeder, B.R.M. Lake, S. Demeshko, M.P. Shaver, M. Buback, Macromolecules, 48 (2015) 43294338.

[38] Y. Chapurina, J. Klitzke, L. Casagrande Ode, Jr., M. Awada, V. Dorcet, E. Kirillov, J.F. Carpentier, Dalton Trans., 43 (2014) 14322-14333.

[39] O. Wichmann, K. Ahonen, R. Sillanpää, Polyhedron, 30 (2011) 477-485.

[40] T. Karimpour, E. Safaei, A. Wojtczak, Z. Jagličić, A. Kozakiewicz, Inorg. Chim. Acta, 395 (2013) 124-134.

[41] R. van Gorkum, J. Berding, A.M. Mills, H. Kooijman, D.M. Tooke, A.L. Spek, I. Mutikainen, U. Turpeinen, J. Reedijk, E. Bouwman, Eur. J. Inorg. Chem., 2008 (2008) 1487-1496.

[42] S. Heidari, E. Safaei, A. Wojtczak, P. Cotič, A. Kozakiewicz, Polyhedron, 55 (2013) 109-116.

[43] D. Loits, S. Bräse, A.J. North, J.M. White, P.S. Donnelly, M.A. Rizzacasa, Eur. J. Inorg. Chem., 2016 (2016) 3541-3544.

[44] M. Shi, W.-L. Duan, Appl. Organomet. Chem., 17 (2003) 175-180.

[45] A. Garai, I. Pant, S. Banerjee, B. Banik, P. Kondaiah, A.R. Chakravarty, Inorg. Chem., 55 (2016) 6027-6035.

[46] L.S. von Chrzanowski, M. Lutz, A.L. Spek, Acta Crystallogr. Sect. C: Cryst. Struct. Commun., C63 (2007) $\mathrm{m} 283-\mathrm{m} 288$.

[47] F.-S. Wang, T.-Y. Yang, C.-C. Hsu, Y.-J. Chen, M.-H. Li, Y.-J. Hsu, M.-C. Chuang, C.-H. Peng, Macromol. Chem. Phys., 217 (2016) 422-432. 